\title{
Research outside the Government
}

$I_{\mathrm{T}}$ is a truism to say that in a world of increasing costs and complexity, scientific research-like education and industry-benefits from being organized into large units with correspondingly large budgets and staffs. Is there then any real future for small private research establishments? A case in point is the Animal Health Trust. Does it justify any longer its existence in the face of the Agricultural Research Council ?

The Trust was founded as the Veterinary Educational Trust by the late Dr W. R. Wooldridge in 1942 to provide scholarships and fellowships for veterinary scientists. Although the Agricultural Research Council then provided grants for postgraduate veterinary training, they were insufficient and the Trust had a real part to play. Afterwards, however, the ARC increased the numbers of its training grants and the Animal Health Trust set out instead to establish research stations, seeking in the process fields neglected by the ARC. Its first venture, the Equine Research Station at Newmarket, was a shrewd choice because it tapped the vein of charity among land owners and horse owners. The second venture was the Houghton Poultry Research Station, and again the Trust led the ARC, some say knowingly beating it to the post, although the poultry station is now jointly financed by the Trust and the ARC. Two other stations-the Small Animals Centre, dealing with cats and dogs, and the Farm Livestock Research Centre-have since been established.

Since its foundation the Trust's activities have often drawn attention to gaps in the work of the ARC but, nevertheless, the two organizations have enjoyed good relations. Individuals from both co-operate on specific research projects; the $\mathrm{ARC}$, and the MRC as well, give small grants to staff at Trust laboratories. Apart from the jointly run poultry station, the ARC seems to have no plans for taking over the Trust's laboratories. It seems content to have a small independent organization-the Trust's total budget for the year beginning July 1, 1966, was only $£ 0 \cdot 25$ millionworking in the same general field. This no doubt is because the Trust and the ARC fulfil different roles. For example, the Trust's Farm Livestock Research Centre does contract work for commercial companies which the ARC cannot undertake. At present it is testing, in experimental conditions and in controlled field trials with co-operative farms, anthelmintics (drugs against nematode parasites) for commercial companies. Four years ago, it also developed a live vaccine for domestic animals against Salmonellosis. And, because of its independence, the Trust seems to enjoy the confidence of the farming community which is traditionally suspicious of government organizations - even the ARC and the Ministry of Agriculture. As a result, the Livestock Research Centre has been able to conduct surveys of the breeding of pedigree beef cattle with the co-operation and financial support of the National Cattle Breeders Association.

But not all the work at the Livestock Centre has such immediate commercial implications. A group is working on the life cycle of nematodes and studying the serology and antigenicity of Ascaris in humans and pigs. Are there two species or does the same species of Ascaris infect both man and pigs ? It is estimated that about 600 million people are infected by Ascaris, so it is not surprising that the MRC takes an interest in this work and has given a grant. Another group is working on the problems of fertility in farm animals, and the infectious transmission of drug resistance and the induction of drug resistance by continuously feeding antibiotics to cattle, sheep and pigs is being studied. Although the Trust has a small budget-which is surprising, given British sentimentality about animals -it still fulfils a very useful role in Britain's veterinary science.

\section{Hydrobiology in Latin America \\ from a Correspondent}

IT has often been remarked that South America lacks a whole range of native land mammals, the large herbivores (it has only threc). The subcontinent makes up, however, in richness of freshwater fish species. These have so far been inadequately studiedless thoroughly, for instance, than in tropical Africaand there has been little or no co-operation between research centres in different countrics. The First Regional Meeting on Hydrobiology held this spring at Santa Fé, Argentina, is therefore of special interest. It was jointly sponsored by the Argentinian Consejo Nacional de Investigaciones Cientificas y Tecnicas and the Freshwater Productivity (PF) Section of the International Biological Programme. Argentina, Bolivia, Brazil, Chile, Colombia, El Salvador, Guyana, Uruguay and Venezuela were represented, and visiting scientists from Britain, the United States and West Germany took part as well as the IBP Sectional Convenor and Co-ordinator.

An initial stock-taking with each country giving a national report opened the proceedings. It emerged that the hydrobiological scene in Latin America is enormously rich and varied. All types of ecological environments are represented, from tropical forest to both hot and cold arid zones, and the waters in these are equally varied-with mountain lakes, plain lakes. estuaries and lagoons, and large lakes at high altitude 